\title{
CHARACTERIZATION OF HETEROGENEOUS ARC WELDS THROUGH MINIATURE TENSILE TESTING AND VICKERS-HARDNESS MAPPING
}

\author{
KARAKTERIZACIJA HETEROGENIH ZVAROV S POMOČJO \\ MINIATURNIH NATEZNIH PREIZKUSOV IN MATRIČNIMI \\ MERITVAMI TRDOTE PO VICKERSU
}

\author{
Stijn Hertelé ${ }^{1}$, Jonas Bally ${ }^{1}$, Nenad Gubeljak ${ }^{2}$, Primož Stefane $^{2}$, \\ Patricia Verleysen $^{3}$, Wim De Waele ${ }^{1}$ \\ ${ }^{1}$ Ghent University, Department of Electrical Energy, Systems and Automation, Soete Laboratory, Technologiepark Zwijnaarde 903, \\ 9052 Zwijnaarde, Belgium \\ ${ }^{2}$ University of Maribor, Laboratory for Machine Parts and Structures, Smetanova 17, 2000 Maribor, Slovenia \\ ${ }^{3}$ Ghent University, Department of Materials Science and Engineering, 9052 Zwijnaarde, Belgium \\ stijn.hertele@ugent.be
}

Prejem rokopisa - received: 2015-07-01; sprejem za objavo - accepted for publication: 2015-07-13

doi: $10.17222 /$ mit.2015.157

The heterogeneity of arc-welded connections is often ignored in structural assessments, giving rise to inaccuracies. Improved assessments taking into account heterogeneity require the characterization of local constitutive properties. We have compared two methods to do this: Vickers-hardness mapping and miniature tensile testing. Whereas the former is more straightforward to apply, the latter provides full-range stress-strain data. This paper discusses an experimental comparison of both methods on a heterogeneous arc weld. Miniature tensile tests were performed, using digital image correlation to measure the strain. The specimens were indented to compare their stress-strain response with Vickers hardness. Notwithstanding that small natural flaws invalidated some tests, reliable stress-strain curves were obtained. Vickers hardness testing is a convenient alternative if the yield and ultimate tensile strength are the only points of interest and the corresponding conversion inaccuracy is acceptable.

Keywords: arc weld, heterogeneity, hardness, miniature tensile testing, digital image correlation

Heterogenost obločno zavarjenega zvara pogosto ni upoštevana pri ocenjevanju celovitosti konstrukcij, kar je lahko razlog za nepravilno oceno. Za boljšo oceno, ki upošteva heterogenost, je potrebno določiti lokalne mehanske lastnosti. Avtorji članka so opravili primerjavo dveh metod za določanje lokalnih mehanskih lastnosti: matrično meritev mikrotrdote po Vickersu in miniaturni natezni preizkus. Za razliko od dosedanje prakse neposredne uporabe mejnih vrednosti, se danes uporablja celotna natezna krivulja napetost-deformacija. V članku je opravljena primerjava med obema eksperimentalno dobljenima skupinama podatkov za heterogeni zvarni spoj. Meritve deformacij na miniaturnih nateznih preizkušancih so bile opravljene s stereo optično digitalno merilno metodo. Na vsakemu od miniaturnih nateznih preizkušancev je bila opravljena meritev mikrotrdote po Vickersu, pri čemer so bile izmerjene vrednost mikrotrdote primerjane z natezno krivuljo napetost-deformacija. Kljub dejstvu, da so bili preizkušanci z majhnimi napakami v zvarih izključeni iz analize, so bile dobljene verodostojne vrednosti meje tečenja in natezne trdnosti iz krivulje napetost-deformacija. Pokazalo se je, da je za hitro oceno natezne trdnosti in meje tečenja materiala zvara, matrična meritev mikrotrdote po Vickersu alternativna metoda nateznemu preizkušanju.

Ključne besede: obločni zvar, heterogenost, trdota, miniaturno natezno preizkušanje, digitalne optične meritve

\section{INTRODUCTION}

Arc welds are prone to defects of which the acceptability should be investigated from the viewpoint of structural integrity. The occurrence of different microstructures in a confined area implies potentially strong local variations of stress-strain behaviour (weld heterogeneity), leading to uncontrolled scatter in the accuracy of defect-tolerance predictions. ${ }^{1}$ A first step in accounting for weld heterogeneity in an improved assessment is the experimental characterization of local stress-strain properties. This paper compares two techniques to do this: Vickers-hardness mapping and miniature tensile testing.

The first technique is to characterize the spatial distribution of hardness by applying a large number of adjacent indents. This method indicates variations of strength ${ }^{2}$, but is not linked to ductility and strain-hardening behaviour. When full-range information is desired, miniature tensile testing is an alternative. The associated test procedure, however, is characterized by a large number of technical challenges and requires a careful preparation, execution and analysis of the tests. ${ }^{3}$

The authors have developed and optimized a procedure for miniature tensile testing, and have compared the results of a test program with Vickers hardness data. This paper highlights the challenges that have been addressed to achieve reliable tensile test results, and the relation between hardness and local stress-strain properties. 


\section{S. HERTELÉ et al.: CHARACTERIZATION OF HETEROGENEOUS ARC WELDS ...}

\section{MATERIAL}

Test material was taken from the girth weld of a 914-mm-diameter steel pipeline having a nominal wall thickness of $10 \mathrm{~mm}$, excavated from a natural-gas transmission grid after nearly five decades of operation. The specified minimum yield strength of the microalloyed steel was $415 \mathrm{MPa}$ and the weld was constructed by multipass shielded metal arc welding (SMAW). This weld was selected for its severe heterogeneity, as witnessed by the $49 \mathrm{~N}$ Vickers (HV5) hardness map shown in Figure 1. Traversing from root to cap, the hardness increases by roughly $50 \%$ of its minimum value. Similarly significant variations are to be expected for the yield and ultimate tensile strength given their approximate relation with hardness.

\section{TEST PROGRAM}

Miniature tensile specimens were sampled from the weld by means of electrical discharge machining (EDM) with a $0.25-\mathrm{mm}$-diameter wire electrode. This technique is suitable as no forces are applied to the vulnerable specimens. A dog-bone-shaped block, taken out in the welding direction, was divided into 0.7 - $\mathrm{mm}$-thick slices (Figure 2). Nine specimens were extracted. These were then ground on both sides to a thickness of $0.5 \mathrm{~mm}$, thus removing the brittle heat-affected zone associated with the EDM. The specimens are numbered in a manner that indicates their through-thickness position, starting from the weld root (1) and heading towards the weld cap (9). The adopted dog-bone geometry has a nominal crosssectional area of $1 \mathrm{~mm}^{2}$. It was developed at the GKSS research centre (Helmholtz-Zentrum Geesthacht) ${ }^{4}$ and has been adopted by other institutions. ${ }^{5,6}$

Note the prismatic section's ratio of length $(9 \mathrm{~mm})$ to width $(2 \mathrm{~mm})$, allowing us to measure strain using an extensometer whose gauge length is four times the specimen width, in accordance with the standards for conventional tensile testing of metallic materials. ${ }^{7}$ Note a filleted end corner having a radius of $1 \mathrm{~mm}$, providing a unique reference for the specimen orientation with respect to the weldment.

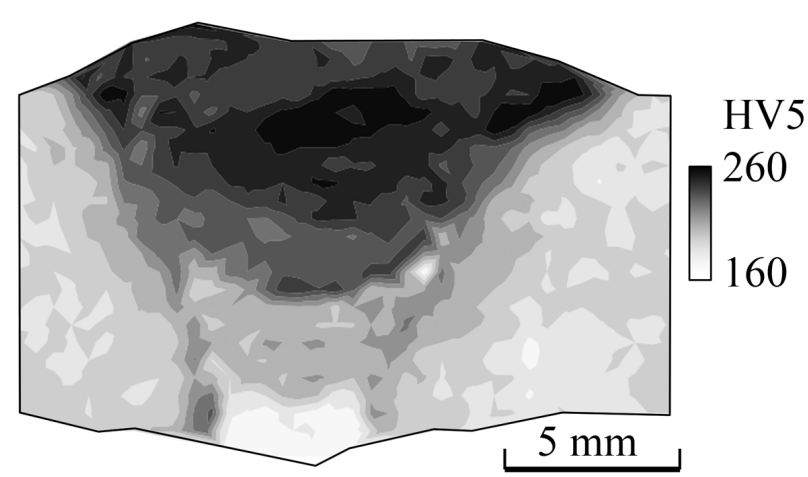

Figure 1: Hardness map of the investigated weld Slika 1: Površinska porazdelitev trdote na analiziranem zvaru
Following grinding, the top and bottom surfaces were polished using 2000-grit sandpaper, on average reducing the roughness $R_{\mathrm{a}}$ (measured in a longitudinal track) from $0.26 \mu \mathrm{m}$ to $0.026 \mu \mathrm{m}$. The side faces were also polished (using 1200-grit sandpaper) to remove the burrs resulting from the grinding process. Without this step, specimenwidth measurements would have been biased, giving rise to an estimated error of $10 \%$ on the stress calculation.

For all nine specimens, the net section width and thickness were measured at five equidistant positions. Small coefficients of variance were observed between all 45 values of the width $(0.82 \%)$ and thickness $(1.74 \%)$, indicating a sound dimensional repeatability of the specimen production. The specimen-specific coefficients of variance did not exceed $0.5 \%$ for the width and $1.0 \%$ for the thickness.

To examine the correlation between the Vickers macrohardness and the tensile-test characteristics, a total of twelve HV5 measurements were performed in the clamping faces of each specimen (six at either end of the specimen). ASTM E $384^{8}$ was consulted to confirm that a specimen thickness of nominally $0.5 \mathrm{~mm}$ is sufficient to obtain valid HV5 indentations, and to ensure a sufficient spacing between the adjacent indentations.

After polishing and hardness testing, specimens were painted white, followed by applying black speckles for the purpose of monitoring strain by means of digital image correlation (DIC). This is an optical measurement technique that allows us to track full-field displacements by following the movements of a random pattern. Next, a 'virtual extensometer' measurement of strain can be output from the obtained displacement data. A stand-alone system provided by Limess $\mathrm{GmbH}$, adopting the VIC3D software (version 2009) of Correlated Solutions Inc, was used for the DIC analysis.

Particularly challenging was the application of a high-quality speckle pattern. Optimal DIC accuracy requires an average speckle size of around $3 \times 3$ camera pixels. ${ }^{9}$ From the camera resolution and the dimensions
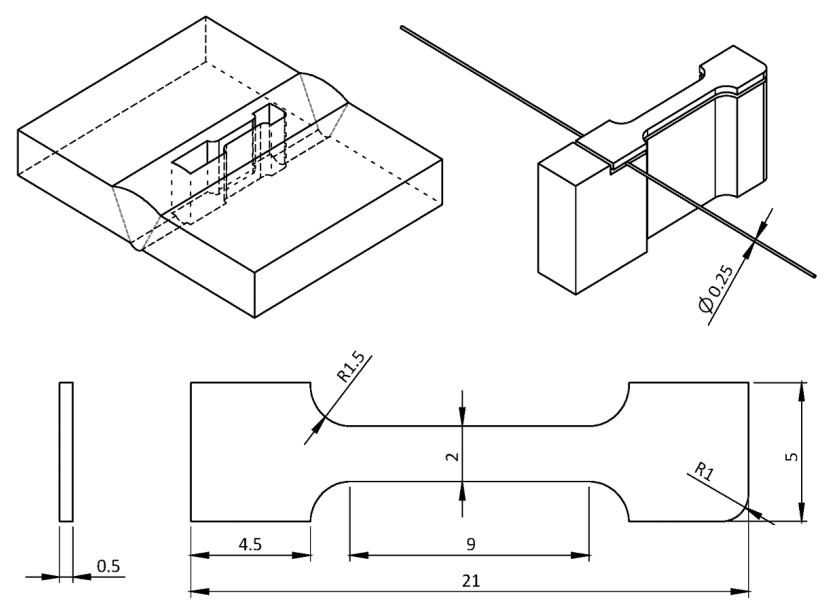

Figure 2: Sampling plan and geometry of miniature tensile specimens Slika 2: Plan izreza vzorcev in geometrija 
of the area of interest, a desired speckle size of $18 \times 18 \mu \mathrm{m}$ followed. The literature indicated that such a speckle size can be achieved by non-conventional methods such as dispersing and heating graphite powder on the surface, or contact lithography. ${ }^{9}$ For this project, however, conventional painting was performed by means of an in-house-developed spray procedure using a nozzle airbrush. The optimization of paint viscosity, nozzle opening, airbrush pressure and spray angle eventually allowed us to create patterns having the desired speckle size with sufficient repeatability. Figure 3 shows a speckled specimen and a close-up of the pattern at a pixel level, confirming the ability to obtain the desired fine speckle size.

The miniature tensile tests were executed using a $5-\mathrm{kN}$ Deben stage, made available by TU Delft for the purpose of this study. Specimens were clamped between grips that were actuated at a fixed displacement rate, which was empirically tuned to limit the stress rate in the linear-elastic region to a value below $11.5 \mathrm{MPa} / \mathrm{s}$ (as required by ASTM E8M ${ }^{7}$ for the standard tensile testing of metallic materials). The tests were stopped upon fracture. The load was recorded and coupled with DIC images that were taken at a rate of $0.5 \mathrm{~Hz}$. To obtain stress-strain data, the stress was calculated by dividing the tensile load by the average values of the net section width and thickness. The strain was obtained from DIC by means of a 'virtual extensometer' having a gauge length of $8 \mathrm{~mm}$, as discussed above.

\section{RESULTS AND DISCUSSION}

This section focuses on three aspects of the test program: the validity of the miniature tensile test results, the observations related to weld heterogeneity, and the relation between the Vickers hardness and the strength characteristics.

Of all nine specimens, three specimens (3,4 and 9) clearly showed an anomalous response, characterized by localized necking at unexpectedly low strain values. Post-mortem fractography revealed weld porosities in each of these specimens. The relative size of such porosi-

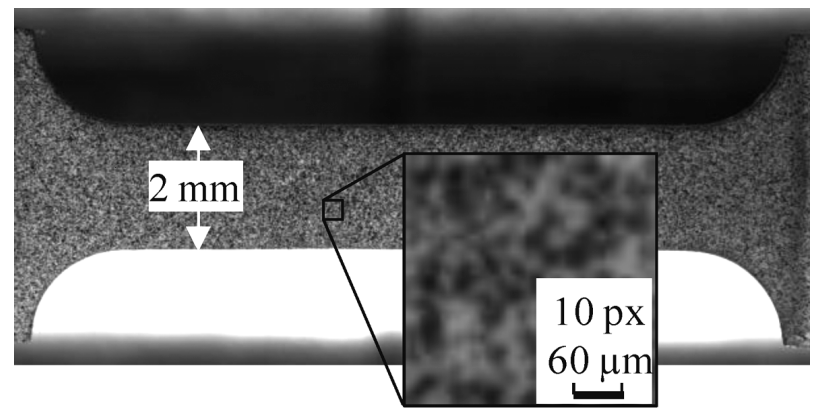

Figure 3: Speckle pattern for the strain analysis using digital image correlation

Slika 3: Raster za meritev deformacij z uporabo optične digitalne merilne tehnike

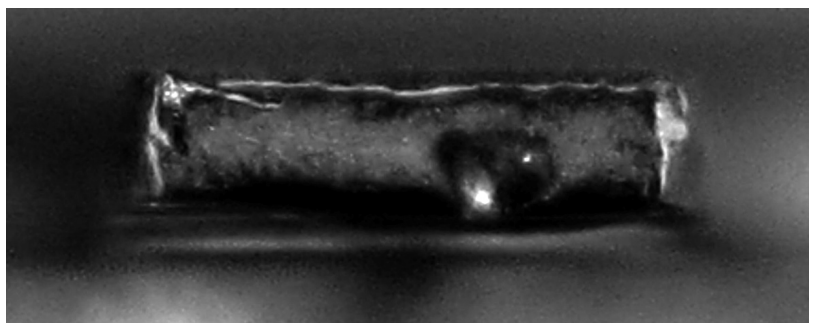

Figure 4: Weld porosities invalidated three miniature tensile test results

Slika 4: Pore v zvarnem spoju so povzročile odstopanje v rezultatih na nateznih preizkušancih

ties with respect to miniature tensile specimens is clearly sufficient to invalidate their test result (Figure 4).

No irregularities were observed on the fracture surfaces of the other specimens, which behaved in an expectable manner. Their stress-strain curves are depicted in Figure 5. Weld heterogeneity is reflected in many aspects. Obviously, yield strength (expressed as $0.2 \%$ proof stress $R_{\mathrm{p} 0.2}$ ) and tensile strength $R_{\mathrm{m}}$ vary considerably (493 MPa $<R_{\mathrm{p} 0.2}<672 \mathrm{MPa}$ and $570 \mathrm{MPa}<R_{\mathrm{m}}<$ $794 \mathrm{MPa}$ ). In addition, there are strong variations in the ductility and strain-hardening behaviour. Comparing specimen 1 with 8 , the former has a Lüders plateau and a uniform elongation (strain at $R_{\mathrm{m}}$ ) of $10.1 \%$, whereas the latter shows round-house yielding and a uniform elongation of $4.3 \%$. The extent of the strain hardening is also variable, as reflected in the ratio $R_{\mathrm{p} 0.2} / R_{\mathrm{m}}$, which varies between 0.80 and 0.89 .

The variety of the stress-strain curve shapes in Figure 5 indicates the limitation to the use of Vickers hardness as a unique number to characterize local properties. Nonetheless, the literature and standards suggest that hardness may be used to estimate $R_{\mathrm{p} 0.2}$ and $R_{\mathrm{m}}$. For instance, the following Equation (1), proposed for steel weld metal in ISO 15653 (in MPa): ${ }^{3}$

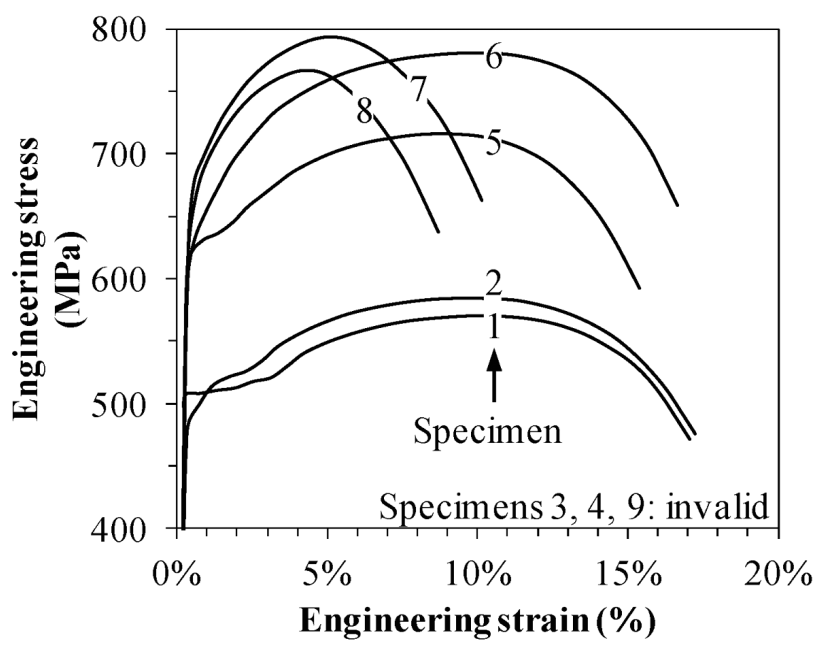

Figure 5: Test results indicate a significant heterogeneity of the constitutive properties

Slika 5: Rezultati nateznih preizkusov kažejo heterogenost v mehanskih lastnostih 


$$
\left\{\begin{array}{l}
R_{\mathrm{p} 0.2}=2.35 \mathrm{HV}+62.0 \\
R_{\mathrm{m}}=3.00 \mathrm{HV}+22.1
\end{array}\right.
$$

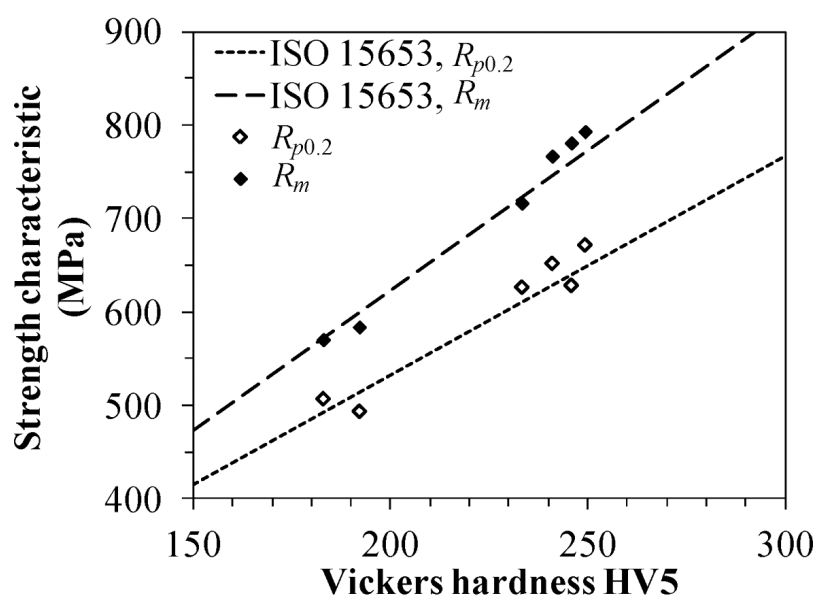

Figure 6: ISO 15653 describes the observed relations between hardness and strength

Slika 6: ISO 15653 kaže razmerje med trdoto in trdnostjo ter odstopanje od eksperimentalno dobljenih vrednosti

The six hardness values at one specimen end may significantly differ from those at the other end (up to 33 $\mathrm{HV}$ difference between the average values from either end). This observation indicates weld heterogeneity in the weld direction (perpendicular to the section shown in Figure 1). As the weakest cross-section governs the failure load of the tensile specimen, the average hardness value of the weakest specimen end was considered for a comparison with strength properties (Figure 6). Equation (1) succeeds in describing the observed relations between the hardness and the strength characteristics. For the six valid tests, predicting $R_{\mathrm{p} 0.2}$ and $R_{\mathrm{m}}$ from HV5 results in errors below $25 \mathrm{MPa}$. The prediction accuracy is higher for $R_{\mathrm{m}}$ than for $R_{\mathrm{p} 0.2}$ (average absolute value of error 14.5 $\mathrm{MPa}$ and 18.5 $\mathrm{MPa}$, respectively).

\section{CONCLUSIONS}

This paper has shown the potential merit of miniature tensile testing to characterize weld stress-strain heterogeneity. The careful specimen preparation and execution of the tests are essential for this. The following attention points of the experimental procedure have been high- lighted: specimen polishing, accurately measuring crosssection dimensions, and applying a suitable speckle pattern for optical strain monitoring. Test validity requires that the specimen is free of any natural weld defects such as porosities.

Comparing the miniature tensile test results with the Vickers hardness testing has pointed out the suitability of the latter (more straightforward) method, provided the desired information is limited to the evolution of the strength variations and, hereto, small strength estimation errors are allowed. Vickers hardness testing does not provide direct information with respect to the ductility or the nature of the strain hardening.

\section{Acknowledgements}

The authors wish to acknowledge the financial support of BOF UGent (grant BOF12/PDO/049), FWO Vlaanderen and ARRS Slovenia (joint FWO grant G.0609.15N), and the kind permission of TU Delft to use their $5-\mathrm{kN}$ test stage.

\section{REFERENCES}

${ }^{1}$ M. Koçak, S. Webster, J. J. Janosch, R. A. Ainsworth, R. Koers (Eds.), Fitness for service procedure, FITNET, MK8, Vol. 1: Procedure, GKSS Research Centre, Geesthacht, Germany 2008

${ }^{2}$ ISO 15653: Metallic materials - method for the determination of quasistatic fracture toughness of welds, ISO, 2010

${ }^{3}$ D. A. LaVan, W. N. Sharpe, Tensile testing of microsamples, Experimental Mechanics, 39 (1999) 3, 210-216, doi:10.1007/ BF02323554

${ }^{4}$ M. Koçak, Structural integrity of welded structures: process - property - performance relationship, $63^{\text {rd }}$ Ann. Assembly \& Int. Conf. Int. Instit. Weld., Istanbul 2010, 3-19

${ }^{5}$ D. Dobi, E. Junghans, Determination of the tensile properties of specimens with small dimensions, Kovine zlitine tehnologije, 33 (1999) 6, 451-457

${ }^{6}$ S. Hertelé, N. Gubeljak, W. De Waele, Advanced characterization of heterogeneous arc welds using micro tensile tests and a two-stage strain hardening ('UGent') model, International Journal of Pressure Vessels and Piping, 119 (2014) 9, 87-94, doi:10.1016/j.ijpvp.2014. 03.007

${ }^{7}$ ASTM E8M: Standard test method for tension testing of metallic materials, ASTM International, 2011

${ }^{8}$ ASTM E384: Standard test method for Knoop and Vickers hardness of materials, ASTM International, 2011

${ }^{9}$ M. A. Sutton, J. J. Orteu, H. W. Schreier, Image correlation for shape, motion and deformation measurements, Springer, USA 2009, doi:10.1007/978-0-387-78747-3 